\title{
Peas in a pod: Canadian and Australian banks before and during a Global Financial Crisis
}

\author{
D.E. Allen ${ }^{a}, \underline{\text { R.R. Boffey }}{ }^{a}$ and R.J. Powell ${ }^{a}$ \\ ${ }^{a}$ School of Accounting, Finance and Economics, Faculty of Business \& Law, Edith Cowan University, \\ Western Australia \\ Email: r.boffey@ecu.edu.au
}

\begin{abstract}
In the aftermath of the Global Financial Crisis (GFC), the Canadian and Australian banking systems have been singled out by some commentators as having performed better than many other banking systems, particularly those in Europe, America and the United Kingdom. Banks in both Canada and Australia, for instance, have continued to report enviable earnings, sound capital levels, and high credit ratings both before and during the GFC. The G-20 and the European Union have tried to identify the features of the Canadian and Australian financial systems which have underpinned this success in order to use them in shaping a revised international regulatory framework. One area of focus has been the regulations governing "quality of capital".

Despite these apparent successes, there is some evidence that both Canadian and Australian banks experienced considerable deterioration in the market value of their assets during the GFC. In this paper we use the KMV / Merton structural methodology, which incorporates market asset values, to examine default probabilities of 9 listed Canadian banks and 13 Australian listed banks in both a pre-GFC period (20002006) and a GFC period (2007-2008). We also modify the model to incorporate conditional probability of default which measures extreme credit risk.

This paper finds that bank risk was significantly similar for Australian and Canadian Banks during the GFC period. This includes an assessment of impaired assets, Value at Risk (VaR) and Distance to Default (DD), as well as the extreme measures of Conditional VaR (CVaR), and Conditional Distance to Default (CDD); metrics which confirm the two countries similarities in terms of a significant increase in credit risk between pre-GFC and GFC periods. The extent of this increase was, however, far more pronounced for Australia, which was coming off a lower base. Bank risk for both countries was found to be far lower than for global counterparts due to factors such as sound regulatory control and low levels of involvement in sub-prime lending. This could provide lessons for global banks on risk management. A key conclusion of the paper is that it is important that fluctuating market values, especially the extreme fluctuations which are measured by $\mathrm{CVaR}$ and $\mathrm{CDD}$, are a key consideration when determining risk management criteria such as capital adequacy.
\end{abstract}

Keywords: Value at Risk; Conditional Value at Risk; Distance to Default; Probability of Default; Conditional Distance to Default; Conditional Probability of Default. 


\section{INTRODUCTION AND BACKGROUND}

Canada and Australia share a number of similar characteristics. Importantly, both were colonies in the British Empire and this has impacted on the characteristics that each has developed. In particular, they share a common head of state. In addition, both countries have a similar geography that involves relatively small populations concentrated in a few large cities; large areas of each continent relatively uninhabited; and an endowment of mineral wealth. But there are, of course, differences. One is the difference of their respective locations: one in the northern hemisphere and the other in the southern hemisphere with a very large distance separating them. A second difference that flows on from this is the increasingly Asian orientation of Australia as against Canada's unavoidable orientation to the US. A third difference is the French influence in Canada, which is without parallel in Australia.

The popular press contains many references to how the two countries are similar (E.g.,Sales (2003)). Academic research has also identified similarities as well as differences in a number of different contexts (E.g.,Brooks (2009)). In addition, there have been fora such as the 2010 Australia Canada Economic Leadership Forum (Canadian Australian Chamber of Commerce, 2010) which have looked to develop the synergies between the two countries.

Possibly, the most recent, systematic, and comprehensive comparison of the two countries is by MacMillan \& McKenzie (2002) who examine how trade, aviation, military, constitutional, imperial, and diplomatic relations between Canada and Australia have changed during the twentieth century. They conclude that similarities between the two countries have underpinned the cooperation and cordiality that is a feature of the relationship.

With the occurrence of the Global Financial Crisis (GFC), a new area of similarity between the two countries has emerged: "the relative resilience of our banking sectors" (Stevens, 2009). In this speech, RBA Governor Stevens highlights the profitable and well capitalised status of Canadian and Australian banks following the GFC. He attributes this to two main factors: the relatively modest holdings of complex securities which were at the centre of the crisis; and the more conservative lending practices by banks in their home markets. In his concluding remarks, Stevens (2009) notes that, relative to the US, UK and European experience, the two countries financial and regulatory systems have "performed pretty well ... and ... are largely free of serious problems" (Stevens, 2009, p. 10).

Dickinson (2010a) produces a detailed comparison of Canadian and Australian banks following the GFC in order to better understand why they had performed relatively so well. He identifies a number of factors, including the past conservatism of Canadian and Australian regulatory requirements regarding capital adequacy; the lack of compromised lending standards; and a focus on domestic lending (Dickinson, 2010b). Ratnovski and Huang (2009) undertake similar analysis, but only focus on Canadian banks and their balance sheets. They identify similar factors to those identified by Dickinson (2010b): the capital regulations which reduced Canadian banks' desire to take risks; and ample retail and depository funding. The benefit of strong bank regulation in Canada and Australia is a sentiment also echoed by Smith (2010). Dickinson (2010a) notes that both the European Union and the G-20 are looking to modify their banking regulations in the light of the Canadian and Australian experience.

Given this promotion of Canada and Australia as exemplars of bank regulation in the time of a GFC, the current research aims to take a different perspective from the previous research by investigating how well banks in these two countries performed from the viewpoint of market values. The techniques of Value at Risk (VaR) and Distance to Default (DD), as well as the extreme measures of Conditional VaR (CVaR), and Conditional Distance to Default (CDD) are used here. The next section of the paper provides background information on the banking industry in Australia and Canada. Section 2 deals with data and methodology. Section 3 covers the results and discussion, with conclusions provided in Section 4.

\subsection{The Banking Industry in Australia and Canada}

The Australian Prudential Regulation Authority (APRA) regulates all Authorised Deposit-taking Institutions (ADI's) in Australia. As per statistics from APRA (2009) and the RBA (2009a), ADI's comprise 58 banks, 11 building societies, and 129 credit unions. Of the 58 banks, 13 are Australian owned comprising $88 \%$ of total bank assets). The remainder are subsidiaries or branches of foreign banks comprising $12 \%$ of total bank assets). The industry is dominated by the four major banks, which comprise approximately $75 \%$ of ADI's total assets. These banks include Westpac, the Australia and New Zealand Banking Corporation (ANZ), the National Australia Bank (NAB), and the Commonwealth Bank of Australia (CBA). These figures include the assets of St. George Bank and the Bank of Western Australia (BankWest) who have recently merged with Westpac and CBA respectively. 
The Canadian Bank regulator is the Office of the Canadian Superintendent of Financial Institutions (OSFI). Figures provided by the OSFI (2009) show Canada has a total of 78 banks with assets totalling USD \$3 trillion. 22 of these are domestic banks, with the others being primarily branches of foreign banks. Of the 22 domestic banks, 9 are public companies listed on the Toronto Stock Exchange. The 'Big 5' banks (Royal Bank of Canada, Toronto-Dominion Bank, Bank of Nova Scotia, Bank of Montreal, and Canadian Imperial Bank) have total assets of USD $\$ 2.4$ trillion, approximately $80 \%$ of the total Canadian domestic banking market.

Table 1 shows Australian and Canadian banks continue to grow total assets at a similar rate over the GFC period. Total assets in Australian banks doubled over the past 5 years, a slightly higher growth rate than for Canada, whereas impaired assets showed a fivefold increase. However, because this is off a low base of $0.19 \%$, the peak of $0.95 \%$ is very low in comparison to international standards. Canadian banks more than doubled their increase in impaired assets from $0.4 \%$ to $0.9 \%$. This is a much smaller increase than Australia, but off a higher base. Indeed, Canada's impaired assets, whilst increasing during the GFC, are at lower levels than those of the early 2000's following the tech-stock crash and the terrorist attacks in the US. In comparison to Australia and Canada, the US (Federal Reserve Bank, 2009) and UK (Bank of England, 2009) showed delinquency rates more than trebling from 2007 to 2009 from $2.4 \%$ to $8.8 \%$ and from $2.1 \%$ to $6.6 \%$ respectively.

Table 1. Key Growth and Risk Indicators for Australian Banks

\begin{tabular}{c|cc|cc|}
\cline { 2 - 5 } & \multicolumn{2}{|c|}{ Australia } & \multicolumn{2}{c|}{ Canada } \\
\cline { 2 - 5 } & $\begin{array}{c}\text { Total } \\
\text { assets } \\
\text { Mar-2000 }\end{array}$ & $\begin{array}{c}\text { Impaired } \\
\text { assets }(\%)\end{array}$ & $\begin{array}{c}\text { Total } \\
\text { assets } \\
(\$ b n)\end{array}$ & $\begin{array}{c}\text { Impaired } \\
\text { assets (\%) }\end{array}$ \\
Mar-2001 & 989 & 0.6 & 1,431 & 1.1 \\
Mar-2002 & 1,176 & 0.6 & 1,577 & 1.4 \\
Mar-2003 & 1,153 & 0.7 & 1,651 & 1.6 \\
Mar-2004 & 1,216 & 0.6 & 1,703 & 1.6 \\
Mar-2005 & 1,396 & 0.4 & 1,754 & 1.1 \\
Mar-2006 & 1,536 & 0.3 & 1,877 & 0.6 \\
Mar-2007 & 1,764 & 0.2 & 2,083 & 0.5 \\
Mar-2008 & 2,016 & 0.2 & 2,375 & 0.4 \\
Mar-2009 & 2,463 & 0.3 & 2,727 & 0.5 \\
\cline { 2 - 5 } & 2,694 & 1.0 & 3,021 & 0.9 \\
\hline
\end{tabular}

Figures are calculated from RBA Statistics (2009b) for all banks operating in Australia. Building Societies and Credit Unions are not included. Impaired assets refer to non-accrual assets and restructured assets both on- and off-balance sheet, plus any assets acquired through the enforcement of security conditions. Non-accrual assets have income which may no longer be accrued ahead of its receipt because there is doubt about the ultimate collectability of principal and/or interest. Restructured assets have been modified to provide for concessions of interest or principal exposures. Impaired assets for Canada are calculated as impaired loans and advances as presented in the financial statements compared to total loans and advances as presented on the face of the balance sheet. Impaired assets for Canada follow a similar definition to those for Australia. Canadian total assets and impaired assets are for all banks classified as domestic as obtained from the OSFI (2009). Figures were either taken at the quarterly reporting date shown in column 1 or the closest reporting date to it. For comparison purposes, amounts are all in USD.

Tier 1 and total capital ratios for both countries in Table 2 are well above the regulatory requirements of $4 \%$ and $8 \%$ respectively. Total equity ratio (shareholders funds to total assets) is substantially lower than the total capital ratio for both countries, in line with their high housing loan component which attracts a lower risk weighting than commercial borrowers. The equity ratio of just over 6\% for Australian banks in 2008 is slightly higher than the $5.2 \%$ for Canadian banks, with both countries being substantially higher than the collective ratio of $3.5 \%$ for European banks, but somewhat lower than in the $7.1 \%$ for the US. Equity ratios in all cases are calculated as total shareholder equity / total assets as obtained from Datastream. The differential of approximately 3\% between risk-weighted and absolute capital ratios for Australia is lower than Canada, with Canada's differential of $6 \%$ being similar to other global regions. In Australia, APRA has generally taken a conservative approach to risk weighting assets, for example, applying a higher risk weighting to higher risk non-standard home loans. 
Table 2. Capital and Equity Ratios 2008

\begin{tabular}{lccc} 
& Tier 1 Capital (\%) & Total Capital (\%) & Equity Ratio (\%) \\
\hline Australia & 8.4 & 11.4 & 6.2 \\
Canada & 11.8 & 14.5 & 5.2 \\
\hline
\end{tabular}

Figures for both countries are taken at quarterly reporting date March 2009, or closest reporting date to it. Tier 1 and Total Capital figures are as reported by the banks in accordance with Basel requirements.

Overall, this section has shown that whilst there have been substantial increases in Australian and Canadian bank impaired assets, levels are modest in comparison to other major global areas.

\section{DATA AND METHODOLOGY}

We include all 13 Australian listed banks and 9 listed Canadian banks. For Australia this includes the 4 major banks and 9 smaller / regional banks (88\% of total bank assets in Australia). In Canada this includes the 'big 5 ' and 4 smaller banks (over $80 \%$ of total bank assets in Canada). All data is obtained from Datastream, including 10 years of daily equity prices for each bank, together with required balance sheet data for calculating VaR, CVaR, DD and PD as described below. This includes daily market capitalisation (used in calculation of daily asset values and for weighting banks to calculate VaR and CVaR); and annual total liabilities, current liabilities and long term liabilities (used in calculation of DD). We compare trends for each of the 10 years, as well as dividing data into a pre-GFC period and a GFC period. The GFC period is from 2007-2008 and the pre-GFC period is the 7 years from 2000 - 2006 ( 7 years aligns with Basel Accord Advanced Credit Risk Requirements). We use an F test to compare share price and market asset volatility between the two countries, testing for significance at both the $95 \%$ and $99 \%$ levels.

\subsection{VaR, CVaR, DD and CDD Methodology}

Value at Risk (VaR) is widely used for measuring market risk, with Conditional VaR (CVaR) providing a measurement for extreme risk. VaR's use by banks escalated since adoption by Basel of VaR as the primary measure for calculating market risk capital requirements. The metric measures potential losses over a specific time period at a given level of confidence. There is extensive literature coverage on VaR. Examples include RiskMetricsTM (1994, 1996) who introduced and popularised VaR, Jorion (1996), and comprehensive discussion of VaR by more than seventy recognised authors in the VaR Modelling Handbook and the VaR Implementation Handbook (2009a, 2009b). In summary, there are 3 methods applied for calculating VaR. The Variance-Covariance (parametric) method introduced by RiskMetrics is the most widely used method by Banks and is the method we use in this study. It estimates VaR on the assumption of a normal distribution. To obtain $\mathrm{VaR}$ for a single asset $\mathrm{X}$, all that needs to be calculated is the mean and standard deviation $(o)$. Using standard distribution tables, and given the normal curve assumption, we automatically know where the worst $1 \%$ and $5 \%$ lie on the curve: $95 \%$ confidence $=-1.645 \sigma_{x}^{\circ}$ and $99 \%$ confidence $=-2.330 o_{x}^{*}$. When calculating $\mathrm{VaR}$, it is usual practice, as used by RiskMetrics, to not use actual asset figures, but rather the logarithm of the ratio of price relatives. That is, the ratio between today's price and the previous price.

A key criticism of VaR is that it says nothing of risk beyond VaR. Critics include Standard and Poor's analysts (Samanta, Azarchs, \& Hill, 2005) due to inconsistency of VaR application across institutions and lack of tail risk assessment. Artzner, Delbaen, Eber, \& Heath $(1999 ; 1997)$ found VaR to have undesirable mathematical properties, such as lack of sub-additivity. Criticism of VaR mounted since the GFC onset with VaR perceived as focussing on historical risk and not measuring tail risk. In addition to VaR, this paper examines CVaR which considers losses beyond VaR. If $\mathrm{VaR}$ is calculated at $95 \%, \mathrm{CVaR}$ is the average of the 5\% extreme returns. Pflug (2000) showed CVaR to be a coherent measure, without the undesirable VaR properties. CVaR has been used in an Australian setting by Allen and Powell (2007), who find significant correlation between $\mathrm{VaR}$ and $\mathrm{CVaR}$ in ranking risk among Australian sectors prior to the GFC and Powell and Allen (2009) who use CVaR to show how relative risk changed among sectors since the GFC onset.

As we are examining $\mathrm{VaR}$ and $\mathrm{CVaR}$ of equities, we weight each bank according to market capitalisation. Correlation among assets in the portfolio is not calculated as we are not calculating VaR for investment purposes, and do not need to show the effect of portfolio diversification. Our total bank figures are based on a weighted average of the underlying bank VaRs. The weighted average is a more meaningful figure to compare individual banks against. VaR is usually measured at high confidence levels, either $95 \%$ or $99 \%$, with CVaR measured as the returns beyond $\operatorname{VaR}(5 \%$ or $1 \%)$. As the GFC period includes only 2 years with 
approximately 250 daily returns (based on the number of trading days), for a confidence level of $99 \%$, CVaR would only encompass 2.5 returns for each of the 2 years, giving 5 returns in total for each bank. We have thus chosen $\mathrm{CVaR}$ at $5 \%$ (VaR 95\%), which provides analysis of a reasonable number of extreme returns.

Share price market risk, which we use VaR and CVaR to measure, is, in turn, a key component of asset price fluctuations which are important to measuring distance to default (DD) and probability of default (PD) using the Merton structural methodology. The firm defaults when asset values fall below debt levels. DD is calculated as:

$$
D D=\frac{\ln (V / F)+\left(\mu-0.5 \sigma_{v}^{2}\right) T}{\sigma_{v} \sqrt{T}}
$$

Where $\mathrm{V}$ is the market value of the firm, $\mathrm{F}=$ face value of firm's debt, and $\mu=$ an estimate of the annual return (drift) of the firm's assets. PD can be determined using the normal distribution. For example, if DD = 2 standard deviations, we know there is a 95\% probability that assets will vary between 1 and two standard deviations. There is a $2.5 \%$ probability that they will fall by more than 2 standard deviations. Using $\mathrm{N}$ as the cumulative standard normal distribution function, $\mathrm{PD}$ is measured as:

$$
P D=N(-D D)
$$

Moody's KMV (Crosbie \& Bohn, 2003) is a popular model used by banks to measure PD. KMV calculates DD based on the Merton approach, but instead of using a normal distribution to calculate PD, KMV use their own worldwide database to determine PD associated with each default level. In KMV, debt is taken as the value of all short-term liabilities (one year and under) plus half the book value of all long term debt outstanding, and this is the approach we use in this study. $\mathrm{T}$ is usually set as 1 year. Using equity returns and the relationship between equity and assets, we estimate an initial asset return. Daily log return is calculated and new asset values estimated for every day. Following KMV, this is repeated until asset returns converge.

Allen and Powell (2009) have modified the Merton model to incorporate a CVaR approach due to the fact that firm's are most likely to default under extreme circumstances. We use this approach, whereby instead of using the standard deviation of all asset returns, we use the standard deviation of the worst $5 \%$ of returns (which we call CStdev) to calculate Conditional Distance to Default (CDD) and conditional Probability of Default (default conditional upon asset values fluctuating at the extreme $5 \%$ level):

$$
\begin{aligned}
& C D D=\frac{\ln (V / F)+\left(\mu-0.5 \sigma_{v}^{2}\right) T}{C S t d e v_{v} \sqrt{T}} \\
& C P D=N(-C D D)
\end{aligned}
$$

\section{RESULTS AND DISCUSSION}

Figure 1 compares yearly VaR, CVaR, DD and CDD between Australian and Canadian Banks using 3 point polynomial trend lines, with metrics calculated as explained in the methodology section. The graphs show risk reducing during the mid-2000's and increasing sharply over the GFC period. Canada's graphs are flatter, having higher risk than Australia earlier on and most noticeably with CDD, and slightly lower on all measures during the GFC. The higher risk measures for Canada during the early 2000's are attributable to several factors. In particular, due to high reliance on the US economy, Canada's markets during this early pre-GFC period mirrored US markets to a large extent. First, global share markets entered a much anticipated cool-off following a period of very high growth during the 1990s. Second, the US Federal Reserve Bank and many other Central Banks made several interest rate increases to cool spending and inflation. Third, the dot-com bubble burst in March 2000, sending high tech stocks tumbling. Fourth, the terrorist attacks of September 11, 2001 caused further market decline. Canada experienced problems such as high unemployment and volatility in the telecommunications and technology sectors in the early 2000's. It was only after 2003 that markets entered a period of sustained growth, which continued up until the start of the GFC. This period of growth and stability is reflected in lower VaR and CVaR values in the mid-2000's. Using $\mathrm{F}$ tests to compare volatility in equity and assets between the two countries, we find that differences in all four volatility measures (VaR, CVaR, Stdev and CStdev) are significant at the $99 \%$ level pre-GFC, but are not significant at either the $99 \%$ or $95 \%$ level during the GFC. That is, they had similar levels of risk during the GFC. 


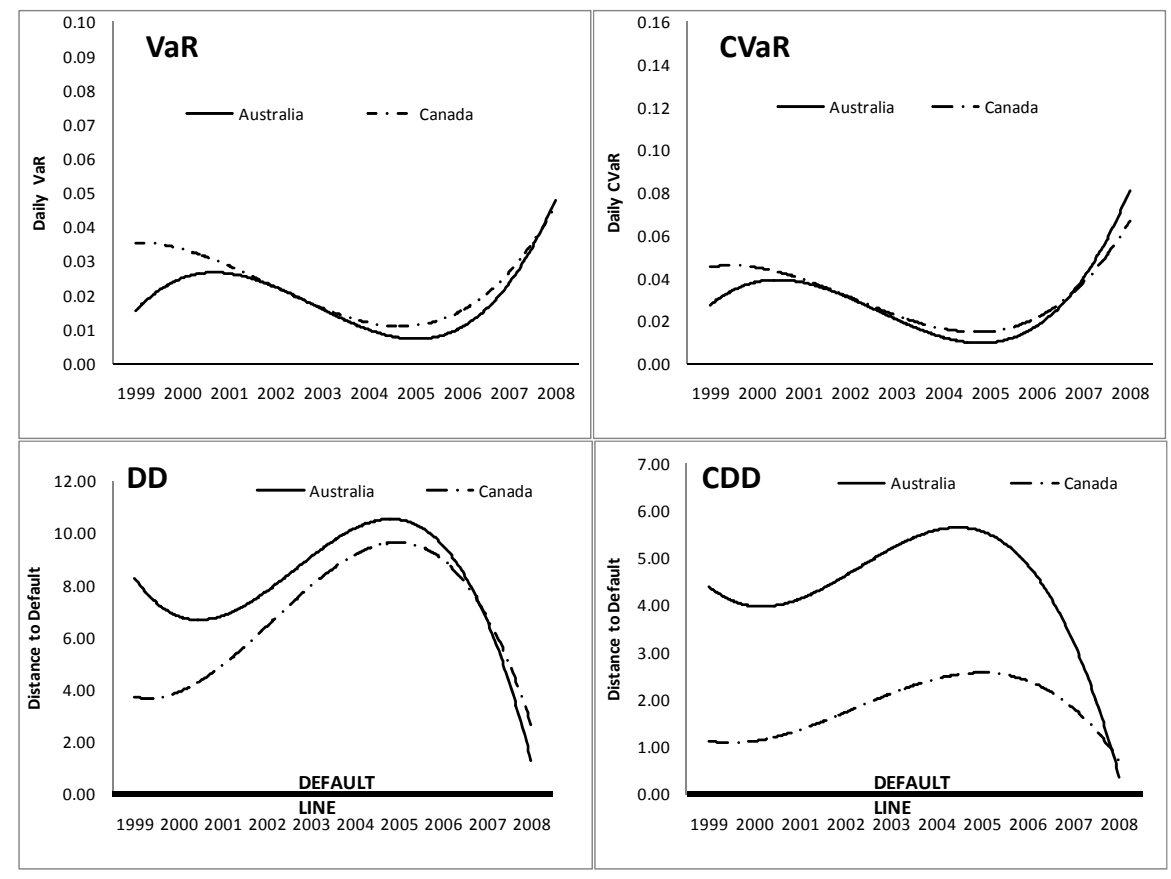

Figure 1 Polynomial trend comparison of Australian and Canadian banks using VaR, CVar, DD, and CDD

Despite Australian and Canadian banks performing better than many global areas, our study shows large increases in bad debts and equity/asset fluctuations, particularly in Australia. There are several factors contributing to this. The fallout in global financial markets, particularly in the US and Europe, and the failure of major banks such as Lehman Brothers and Northern Rock, sparked fears of contagion to all global markets. Additionally, wholesale and securitisation markets dried up, making it extremely difficult for banks to obtain funding. This was exacerbated by market conditions being very poor for raising capital, and by market fears of rising unemployment and increasing corporate failures affecting loan repayments.

\section{CONCLUSIONS}

This paper shows how bank risk was significantly similar for Australian and Canadian Banks during the GFC period. This includes an assessment of impaired assets, VaR, and DD; as well the extreme measures of CVaR, and CDD. These metrics collectively confirm the similarities between these two countries: both countries showed a significant increase in credit risk between pre-GFC and GFC periods, but the extent of this increase was far more pronounced for Australia which came off a lower base. These increases highlight the importance of factoring market fluctuations, as measured by the metrics used in this paper, into risk management criteria such as capital and provisions. Despite these fluctuations, bank risk for both countries was far lower than for global counterparts due to factors such as sound regulatory control and low levels of involvement in sub-prime lending, which provides lessons for global banks on risk management.

\section{ACKNOWLEDGEMENTS}

The authors would like to thank the Australian Research Council for funding support.

\section{REFERENCES}

Allen, D. E., \& Powell, R. (2007). Industry market value at risk in Australia. from www.business.ecu.edu.au/users/dallen/wp0704da.pdf

APRA. (2009). List of Authorised Deposit-taking Institutions. Retrieved 27 August 2009, from http://www.apra.gov.au/ADI/ADIList.cfm

Artzner, P., Delbaen, F., Eber, J., \& Heath, D. (1999). Coherent measures of risk. Mathematical Finance, 9, 203-228.

Artzner, P., Delbaen, F., Eber, J. M., \& Heath, D. (1997). Thinking coherently. Risk, 10, 68-71. 
Bank of England. (2009). Bankstats. Retrieved 12 January, 2010, from www.bankofengland.co.uk/statistics/

Brooks, K. (2009). Tax treaty treatment of royalty payments from low-income countries: A comparison of Canada and Australia's policies. eJournal of Tax Research, 5(2), 168-197.

Canadian Australian Chamber of Commerce. (2010). 2010 Australia Canada Economic Leadership Forum Retrieved 2011, July 4, from http://www.cacc.com.au/Default.aspx?pageId=882780

Dickinson, A. (2010a). Canadian Economy and Major Banks: A Comparison With Australia (KPMG Study). Sydney: KPMG.

Dickinson, A. (2010b). How Australian and Canadian banks both avoided the worst of the financial crisis. KPMG Banking Newsletter Retrieved July 4, 2011, from http:/www.kpmg.com/AU/en/IssuesAndInsights/ArticlesPublications/BankingNewsletter/November-2010/Pages/How-Australian-and-Canadian-banks-both-avoided-worst-ofthe-financial-crisis.aspx

Federal Reserve Bank. (2009). Federal Reserve Statistical Release. Charge-off and Delinquency Rates. Retrieved 27 December, 2009, from www.federalreserve.gov

Gregoriou, G. N. (2009a). The VaR Implementation Handbook. New York: McGraw Hill.

Gregoriou, G. N. (2009b). The VaR Modeling Handbook. New York: McGraw Hill.

J.P. Morgan, \& Reuters. (1994, 1996). RiskMetrics Technical Document.

Jorion, P. (1996). Value at Risk: The New Benchmark for Controlling Derivative Risk: Irwin Professional Publishing.

MacMillan, M., \& McKenzie, F. (Eds.). (2002). Parties Long Estranged: Canada and Australia in the Twentieth Century. Vancouver: UBC Press.

Office of the Superintendent of Financial Institutions Canada. (2009). Financial Data - Banks. Retrieved 12 January 2010, from http://www.osfi-bsif.gc.ca

Pflug, G. (2000). Some Remarks on Value-at-Risk and Conditional-Value-at-Risk. In R. Uryasev (Ed.), Probabilistic Constrained Optimisation: Methodology and Applications. Dordrecht, Boston: Kluwer Academic Publishers.

Powell, R., \& Allen, D. (2009). CVaR and Credit Risk Management. In Anderssen, R.S., R.D. Braddock and L.T.H. Newham (eds) 18th World IMACS Congress and MODSIM09 International Congress on Modelling and Simulation. Modelling and Simulation Society of Australia and New Zealand and International Association for Mathematics and Computers in Simulation, July 2009, pp. 1508-1514.

Ratnovski, L., \& Huang, R. (2009). Why are Canadian banks more resilient? IMF Working Paper WP $09 / 152$.

Reserve Bank of Australia. (2009a). The main types of financial institutions in Australia. Retrieved 26 August 2009, from http://www.rba.gov.au/fin-stability/index.html

Reserve Bank of Australia. (2009b). Statistics. Retrieved 28 August 2009, from http://www.rba.gov.au/statistics/

Sales, L. (2003, March 7). Australia - Canada comparisons. Retrieved July 4, 2011, from http://www.abc.net.au/worldtoday/stories/s801557.htm

Samanta, P., Azarchs, T., \& Hill, N. (2005). Chasing their tails: Banks look beyond Value-At-Risk. RatingsDirect. Retrieved from http://www2.standardandpoors.com/portal/site/sp/en/us/page.article/2,1,6,4,1126533408950.html

Smith, P. (2010). Australian regulator hits out at global bank tax plans. Financial Times. Retrieved from www.ft.com/cms/s/0/14e2357e-4ef8-11df-b8f4-001144feab49a.htiml

Stevens, G. (2009). Australia and Canada - Comparing notes on recent experiences. Reserve Bank of Australia Bulletin, June 2009, 36-44. 